\title{
EFEKTIVITAS PEMBERSIHAN LANTAI KAMAR OPERASI ZONA4 DAN JUMLAH KOLONI BAKTERI DI INSTALASI BEDAH SENTRAL
}

\author{
Fiashriel Lundy, Tavip Dwi Wahyuni, Tri Johan Agus Yuswanto \\ Poltekkes Kemenkes Malang, Jalan Besar Ijen No 77 C Malang \\ Email: fiashriellundy@yahoo.com
}

\section{THE EFFECTIVENESS OF THE OPERATING ROOM FLOOR CLEANING ZONE 4 AND NUMBER OF BACTERIAL COLONIES INTHE CENTRAL SURGICALINSTALLATION (IBS)}

\begin{abstract}
The purpose of this research is to know the effectiveness of the operating room floor cleaning zone 4 against the number of bacterial colonies in the Central Surgical Installation (IBS). The research design used in the study was analytical cross sectional observatif. The sample of this research is the operating room floor clean contaminated and dirty operating room floors were taken with a swab of the floor on the 3rd round in IBS Ngudi Waluyo Wlingi hospital. Data collection using the observation sheet the number of bacterial colonies and observation sheet floor cleaning operating room zone 4. The results of this research show that meaning there is the effectiveness of the operating room floor cleaning zone 4 against the number of colonies of bacteria on the floor. The recommendations of the study results is the need for caution in terms of cleaning the floor primarily to press the number of the number of bacteria on the floor of an operating room floor in particular zone 4.
\end{abstract}

Keywords: room oprasi floor cleaning Effectiveness, zone 4, the number of bacterial colonies.

\begin{abstract}
Abstrak: Tujuan penelitian ini adalah untuk mengetahui keefektifan pembersihan lantai kamar operasi zona 4 terhadap jumlah koloni bakteri di Instalasi Bedah Sentral (IBS) RSUD Ngudi Waluyo Wlingi. Desain penelitian yang digunakan dalam penelitian ini observatif analitik Cross Sectional. Sampel dari penelitian ini ialah lantai kamar operasi bersih terkontaminasi dan lantai kamar operasi kotor yang diambil dengan swab lantai pada 3 ronde di IBS RSUD Ngudi Waluyo Wlingi. Pengumpulan data menggunakan lembar observasi jumlah koloni bakteri dan lembar observasi pembersihan lantai kamar operasi zona 4. Hasil penelitian ini menunjukkan bahwa p value <0,05 yaitu 0,004 <0,05yang berarti bahwa ada efektivitas pembersihan lantai kamar operasi zona 4 terhadap jumlah koloni bakteri di lantai. Rekomendasi hasil penelitian ini ialah perlunya perhatian dalam hal melakukan pembersihan terutama lantai untuk menekan jumlah angka bakteri di lantai khususnya lantai kamar operasi zona 4.
\end{abstract}

Kata Kunci: efektivitas pembersihan lantai kamar oprasi, Zona 4, Jumlah koloni bakteri.

\section{PENDAHULUAN}

Instalasi merupakan bagian integral yang penting dari pelayanan suatu rumah sakit, berbentuk suatu unit yang terorganisir dan sangat terintegrasi, dimana didalamnya tersedia sarana dan prasarana penunjang untuk melakukan tindakan pembedahan. Ruang operasi adalah suatu unit khusus di RS yang berfungsi sebagai tempat untuk melakukan tindakan pembedahan secara elektif maupun akut, yang membutuhkan kondisi streril dan kondisi khusus lainnya (Kemenkes, 2012).

Sebuah kamar operasi merupakan ruangan paling istimewa di rumah sakit yang pengelolaannya paling khusus dibanding ruangan lain pada umumnya. Di ruang operasi segala tindakan invasif bisa dilakukan terhadap tubuh manusia. Untuk menjamin tindakan operasi berjalan lancar dan meminimalkan faktor-faktor pengganggu, maka perlu dilakukan pengendalian kamar operasi yang 
baik. Keberhasilan prosedur dan tindakan medis yang dikerjakan di kamar bedah ini menuntut adanya totalitas persyaratan semua faktor pendukung pelaksanaan pembedahan. Risiko yang tak lepas dari perhatian adalah adanya invasi mikroba patogen, dapat bersumber dari petugas, peralatan medis, lingkungan kerja atau kamar bedah, bahkan dari penderita itu sendiri (Darmadi, 2008).

Kamar bedah secara rutin dan periodik selalu dibersihkan secara teratur. Ini bertujuan untuk tetap mempertahankan sterilisasi dari kamar bedah, sehingga dapat dicegah infeksi nosokomial yang bersumber dari kamar bedah. Pembersihan kamar operasi yang dilakukan dibagi menjadi 3 macam, yaitu pembersihan sewaktu, pembersihan harian, dan pembersihan mingguan (Depkes, 1993). Pembersihan yang dilakukan meliputi pembersihan lantai kamar operasi, pembersihan dinding kamar operasi, pembersihan meja operasi, dan pembersihan peralatan yang berada didalam kamar operasi serta pembersihan lingkungan yang berada diluar kamar operasi.

Salah satu upaya untuk menjaga kebersihan kamar operasi ialah dengan melakukan pembersihan lantai kamar operasi khususnya lantai kamar operasi yang berada pada zona 4 . Pembersihan lantai kamar operasi dilakukan dengan teknik dan jenis desinfektan yang berbeda sesuai dengan prosedur tiap rumah sakit. Tipe dan jenis lantai kamar operasi tiap rumah sakit berbeda sesuai dengan konstruksi jenis bangunan kamar operasi tersebut. Pembersihan lantai kamar operasi tentunya juga dilaksanakan dengan waktu pengepelan yang berbeda-beda. Lantai kamar operasi memiliki nilai atau angka standar kuman lantai kamar operasi. Angka ini tentunya berbeda dengan angka lantai ruangan perawatan. Departemen Kesehatan Republik Indonesia mensyaratkan angka kuman lantai untuk ruang operasi rumah sakit $0-5 \mathrm{CFU} / \mathrm{cm}^{2}$ dan ruang perawatan 5-10 CFU/ $/ \mathrm{cm}^{2}$ (Depkes
RI, 1993).

Pembersihan lantai kamar operasi di RSUD Ngudi Waluyo Wlingi menggunakan cairan klorin $0,05 \%$, dimana cairan tersebut berasal dari cairan klorin $0,5 \%$ yang telah diencerkan oleh pihak depo farmasi. Pembersihan lantai di kamar operasi RSUD Ngudi Waluyo Wlingi menggunakan kain pel dan kain pel setiap kamar operasi berbeda-beda (satu kamar operasi menggunakan satu kain pel khusus untuk kamar operasi tersebut). Apabila ada tumpahan darah dilantai, maka diberi cairan klorin $0,5 \%$ (spill kit) kemudian dilakukan pengepelan dengan menggunakan cairan klorin $0,05 \%$. pengepalan dilakukan oleh petugas cleaning service yang berjumlah 3 orang.

Pembersihan lantai kamar operasi di RSUD Ngudi Waluyo Wlingi setelah tindakan operasi selesai dilakukan dengan waktu yang cepat. Pembersihan lantai kamar operasi apabila kamar operasi akan digunakan lagi untuk pembedahan selanjutnya, pembersihan lantai yang dilakukan tidak secara menyeluruh dan jarak waktu pembersihana lantai kamar operasi untuk tindakan operasai selanjutnya ialah kurang lebih 15 menit. Sistem sterilisasi kamar operasi yang berada di RSUD Ngudi Waluyo Wlingi tidak menggunakan sinar ultraviolet melainkan dengan sistem AHU-HEPA (Air Handling Unit-High Efficiency Particulate Filter).

Kualitas lingkungan di rumah sakit termasuk ruang operasi merupakan suatu hal yang harus diperhatikan, karena beberapa cara transmisi kuman penyebab infeksi dapat terjadi dengan droplet, airbone maupun kontak langsung. Penyebab penyakit dapat berada di udara, lantai, dinding maupun peralatan medis (Suwarni \& Sutomo, 2001). Lingkungan yang terkontaminasi mempunyai peran yang cukup besar sebagai penularan penyakit yang dapat menimbulkan infeksi nosokomial (Widajati, 2008). menurut data WHO, angka kejadian infeksi di RS sekitar $3-21 \%$ (rata-rata 9\%). Infeksi nosokomial 
merupakan persoalan serius yang dapat menjadi penyebab langsung maupun tidak langsung kematian pasien (Taek, 2010).

Tujuan penelitian ini adalah mengetahui keefektifan pembersihan lantai kamar operasi zona 4 terhadap jumlah koloni bakteri di Instalasi Bedah Sentral (IBS) RSUD Ngudi Waluyo Wlingi.

\section{METODE PENELITIAN}

Penelitian ini menggunakan desain deskriptif observasional. Sampel yang diambil pada penelitian ini adalah lantai kamar operasi bersih terkontaminasi dan kamar operasi kotor yang ada di Instalasi Bedah Sentral (IBS) RSUD Ngudi Waluyo Wlingi.

Adapun kriteria inklusi dalam penelitian ini adalah: 1) Lantai kamar operasi bersih terkontaminasi dan kamar operasi kotor. 2) Lantai kamar operasi bersih terkontaminasi dan kamar operasi kotor yang digunakan sebelum tindakan operasi dimulai, 3) Lantai kamar operasi bersih terkontaminasi dan kamar operasi kotor yang digunakan setelah tindakan operasi selesai dan setelah dilakukan pembersihan lantai.

Pengambilan sampel penelitian ini dilakukan secara acak, dimana sampel yang akan diambil yang telah dilakukan pembersihan lantai dengan menggunakan cairan desinfektan oleh cleaning service. Jenis desinfektan yang digunakan (Klorin 0,05\%)

Pengumpulan data dilakukan melalui hasil observasi yang dilakukan selama pembersihan lantai kamar operasi zona 4 dan pengambilan hasil swab yang dilakukan di lantai kamar operasi. Setelah memperoleh hasil swab lantai kamar operasi, peneliti membawa hasil swab tersebut ke Laboratorium Instalasi Penyehatan Lingkungan (IPL).

Data hasil jumlah bakteri dilihat setelah dilakukan pembiakan oleh Instalasi Penyehatan Lingkungan (IPL) kemudian dikategorikan berdasarkan nilai normal jumlah angka bakteri di lantai kamar operasi dengan kriteria sebagai berikut 1) Standard : 0-5 CFU/ $\mathrm{cm}^{2}$ (Colony Forming Unit), 2) Tidak standard : > 5 CFU/ $\mathrm{cm}^{2}$ (Colony Forming Unit)

Selain angka bakteri kamar operasi, peneliti juga melihat hasil pemeriksaan laboratorium terhadap kandungan bakteri Escherichia coli (E.coli). Dari kandungan bakteri tersebut didapatkan hasil positif (+) atau hasil negatif (-). Kemudian peneliti melakukan penghitungan total skor yang didapat berdasarkan observasi yang dilakukan pada cleaning service atau petugas pembersihan lantai kamar operasi zona 4 di Instalasi Bedah Sentral RSUD Ngudi Waluyo Wlingi.

Uji statistik dalam penelitian ini, menggunakan uji statistik Spearman. Uji ini untuk mengetahui hubungan 2 variabel yang ada dalam penelitian ini. Apabila $\mathrm{p}$ value $>0,05$ maka hipotesis $\mathrm{H} 1$ dalam penelitian ini ditolak, jika $\mathrm{p}$ value $<0,05$ maka hipotesis $\mathrm{H} 1$ dalam penelitian ini diterima.

\section{HASIL PENELITIAN}

Instalasi Bedah Sentral (IBS) merupakan salah satu fasilitas penunjang yang dimiliki RSUD Ngudi Waluyo Wlingi, dimana dalam instalasi ini memiliki 8 kamar operasi. Instalasi Bedah Sentral ini merupakan bangunan yang baru dan diresmikan pada Januari 2016. Bangunan ini telah menggunakan sistem sterilisasi ruangan dengan AHU-HEPA (Air Handling Unit - High Efficiency Particulate Filter). Lantai yang terdapat di dalam instalasi bedah sentral ini telah menggunakan bahan anti statik yaitu vinil anti statik dan bewarna cerah. Pintu kamar operasi 1 sampai 8 di IBS ini telah menggunakan sistem sensor pintu geser (sliding door) dimana disetiap pintu terdapat kaca jendela pengintai.

Jumlah petugas pembersihan di kamar operasi berjumlah 3 orang/petugas dan semua petugas berjenis kelamin laki-laki. 2 dari ketiga petugas tersebut memiliki tingkat pendidikan 
SMK. Usia semua petugas kamar operasi berbeda-beda, usia tertinggi ialah 45 tahun dan terendah ialah 22 tahun. Masa lama bekerja yang dimiliki oleh ketiga petugas berbeda-beda yaitu, petugas pertama lama bekerja di kamar operasi 4 tahun, petugas kedua lama bekerja 1 tahun, dan petugas ketiga lama bekerja 3 tahun.

Petugas pembersihan kamar operasi IBS RSUD Ngudi Waluyo Wlingi berjumlah 3 orang/petugas, tetapi petugas yang biasanya melakukan pembersihan lantai kamar operasi hanya dilakukan oleh 2 orang petugas. Karena petugas yang tidak membersihkan lantai kamar operasi melakukan pembersihan lainnya dikamar operasi seperti melakukan pencucian alat-alat instrumen setelah pembedahan dan melakukan pengepakan alat-alat instrumen untuk dibawa ke CSSD.

Tabel 1. Hasil Observasi Petugas Pembersihan Kamar Operasi 1 dan 2 pada Pelaksanaan Pembersihan Lantai Kamar Operasi Zona 4

\begin{tabular}{cccc}
\hline OK & Ronde & $\begin{array}{c}\text { Petugas } \\
\text { Pembersihan }\end{array}$ & $\begin{array}{c}\text { Total } \\
\text { Skor }\end{array}$ \\
\hline \multirow{2}{*}{ OK 2 } & Ronde 1 & Petugas 2 & Cukup \\
& Ronde 2 & Petugas 2 & Kurang \\
& Ronde 3 & Petugas 1 & Kurang \\
& Ronde 1 & Petugas 1 & Cukup \\
OK 3 & Ronde 2 & Petugas 2 & Kurang \\
& Ronde 3 & Petugas 1 & Kurang \\
\hline
\end{tabular}

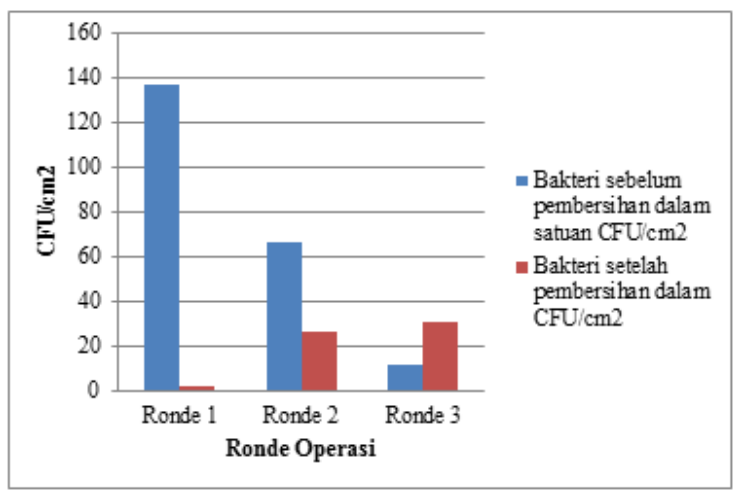

Gambar 1. Jumlah Koloni Bakteri di Lantai Kamar Operasi Bersih Terkontaminasi (OK 2) Sebelum dan Setelah Pembersihan Lantai Kamar Operasi Zona 4 Ronde 1, 2, dan 3
Menunjukkan bahwa hasil observasi yang didapat terhadap pembersihalan lantai kamar operasi zona 4 yang mendapatkan total skor Cukup ialah pembersihan lantai kamar operasi 2 dan 3 pada ronde 1. Sedangkan pada ronde 2 dan ronde 3 pada kamar OK 2 dan OK 3 mendapatkan total skor Kurang.

Berdasarkan gambar 1 menunjukkan bahwa jumlah koloni bakteri dilantai kamar operasi bersih terkontaminasi sebelum dilakukan pembersihan dan sebelum mulai ronde 1 dalam keadaan tinggi yaitu $137 \mathrm{CFU} / \mathrm{cm}^{2}$, sedangkan setelah dilakukan pembersihan lantai pada ronde 1 mengalami penurunan angka bakteri yaitu 2 $\mathrm{CFU} / \mathrm{cm}^{2}$. Saat akan memulai ronde 2, bakteri dalam keadaan tinggi kembali yaitu $67 \mathrm{CFU} / \mathrm{cm}^{2}$, kemudian setelah ronde 2 selesai dan setelah dilakukan pembersihan bakteri menurun menjadi $27 \mathrm{CFU} / \mathrm{cm}^{2}$. Pada ronde 3, bakteri yang terdapat sebesar $12 \mathrm{CFU} / \mathrm{cm}^{2}$ saat sebelum mulai ronde 3 , tetapi setelah ronde 3 selesai dan setelah dilkukan pembersihan bakteri yang terdapat dilantai yaitu sebesar $15 \mathrm{CFU} / \mathrm{cm}^{2}$.

Selain jumlah koloni bakteri pada lantai, hasil swab laboratorium juga memperlihatkan mikroorganisme jenis Escherichia coli.

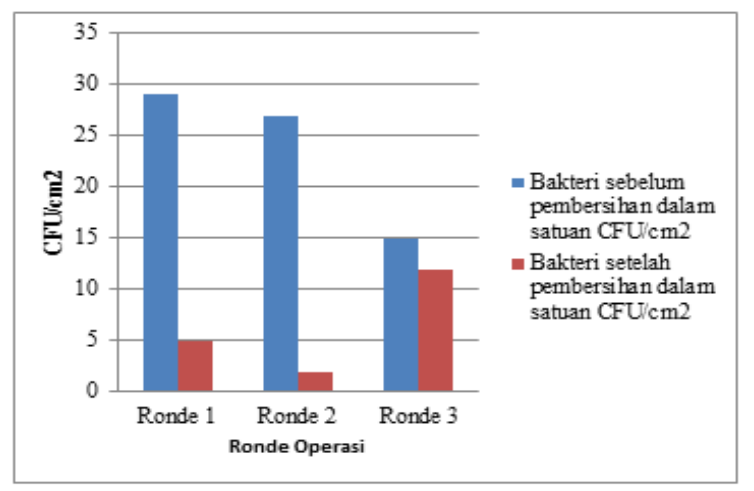

Gambar 2. Jumlah Koloni Bakteri di Lantai Kamar Operasi Kotor (OK3) Terkontaminasi Sebelum dan Setelah Dilakukan Pembersihan Lantai Kamar Operasi Zona 4 Ronde 1, 2, dan 3 
Mikroorganisme ini sebelum dilakukan pembersihan dan setelah dilakukan pembersihan pada lantai kamar operasi zona 4 di kamar operasi bersih terkontaminasi hasilnya Negatif (-). Hal ini menunjukkan bahwa jumlah koloni bakteri dilantai kamar operasi kotor sebelum dilakukan pembersihan dan sebelum mulai ronde 1 dalam keadaan tinggi yaitu $29 \mathrm{CFU} / \mathrm{cm}^{2}$, sedangkan setelah dilakukan pembersihan lantai pada ronde 1 mengalami penurunan angka bakteri yaitu $5 \mathrm{CFU} / \mathrm{cm}^{2}$. Saat akan memulai ronde 2 , bakteri dalam keadaan tinggi kembali yaitu $27 \mathrm{CFU} / \mathrm{cm}^{2}$, kemudian setelah ronde 2 selesai dan setelah dilakukan pembersihan bakteri menurun menjadi $2 \mathrm{CFU} / \mathrm{cm}^{2}$. Pada ronde 3, bakteri yang terdapat sebesar $15 \mathrm{CFU} /$ $\mathrm{cm}^{2}$ saat sebelum mulai ronde 3 , tetapi setelah ronde 3 selesai dan setelah dilkukan pembersihan bakteri yang terdapat dilantai yaitu sebesar 12 $\mathrm{CFU} / \mathrm{cm}^{2}$.

Selain jumlah koloni bakteri pada lantai, hasil swab laboratorium juga memperlihatkan mikroorganisme jenis Escherichia coli. Mikroorganisme ini sebelum dilakukan pembersihan dan setelah dilakukan pembersihan pada lantai kamar operasi zona 4 di kamar operasi kotor hasilnya Negatif(-).

\section{PEMBAHASAN}

Observasi yang dilakukan diketahui bahwa pembersihan lantai di kamar operasi zona 4 tidak memiliki prosedur khusus pembersihan lantai tetapi menggunakan prosedur pembersihan permukaan lingkungan dan pembersihan dilakukan pertama kali pada pagi hari pukul 06.00 WIB sebelum operasi dimulai oleh petugas pembersihan. Kemudian untuk pembersihan selanjutnya dilakukan setelah tindakan operasi selesai dilaksakan dan setelah semua peralatan yang digunakan dalam operasi tersebut dirapikan. Pada pembersihan lantai kamar operasi zona 4 di IBS RSUD Ngudi Waluyo Wlingi meng- gunakan handuk kain pel dan tongkat pel yang terbuat dari besi. Sedangkan cairan yang digunakan dalam pembersihan lantai ialah dengan menggunakan cairan klorin $0,05 \%$.

Dalam pembersihan lantai kamar operasi zona 4, alat pembersihan lantai digunakan satu alat untuk satu kamar operasi dan satu handuk/ kain pel untuk satu kamar operasi. Kain pel yang digunakan dalam pembersihan lantai kamar operasi zona 4 tidak diganti setiap akan melakukan pembersihan lantai tetapi kain pel yang digunakan diganti satu hari satu kali. Cara pembersihan lantai yang dilakukan menurut observasi peneliti di kamar operasi ini ialah dengan menyemprotkan cairan klorin 0,05\% di lantai secara menyeluruh, lalu petugas pembersihan melakukan pembersihan dari depan kebelakang. Setelah pembersihan lantai, alat pembersihan tersebut diletakkan di belakang kamar operasi dan kain pel yang menempel pada alat tersebut tidak di cuci atau diganti.

Efektivitas pembersihan harian pada lantai kamar operasi dapat menurunkan angka kuman pada lantai kamar operasi tetapi ada juga yang dapat meningkatkan angka kuman pada lantai kamar operasi tersebut dengan melihat jenis cairan desinfektan yang digunakan. Cairan yang digunakan dalam pembersihan lantai kamar operasi RSUD Ngudi Waluyo Wlingi menggunakan cairan klorin $0,05 \%$ dan penggunaannya sesuai dengan prosedur dari rumah sakit tersebut.

Hasil observasi yang telah dilakukan, dengan tidak adanya penggantian kain pel setiap akan dilaksanakan pembersihan lantai kamar operasi dapat menjadi salah satu faktor peningkatan jumlah koloni bakteri yang ada dilantai kamar operasi. Karena kain pel yang digunakan tidak di cuci dan dikeringkan tetapi langsung digunakan kembali untuk melakukan pembersihan lantai. Selain itu, pembersihan yang tidak merata yang dilakukan dalam pembersihan lantai kamar operasi juga dapat memicu tumbuhnya bakteri. 
Faktor lain yang dapat memicu berkembangnya bakteri ialah apabila setelah dilakukan pembersihan, daerah yang telah terkena usapan pembersihan terkena sandal oleh petugas pembersihan lantai kamar operasi itu sendiri dan tidak dilakukan pengusapan kembali. Karena dari ketidakrataan tersebut, lantai tidak terkena cairan desinfektan dan tidak terkena usapan pembersihan. Dari hasil observasi terhadap pembersihan lantai kamar operasi zona 4 didapatkan skor tertinggi yaitu cukup dalam hal pembersihan lantai operasi yang dilakukan oleh petugas pembersihan kamar operasi.

Pengambilan swab pertama dikamar operasi 2 didapatkan hasil swab angka bakteri $137 \mathrm{CFU} /$ $\mathrm{cm}^{2}$. Sedangkan untuk kamar operasi 3 dilakukan pengambilan swab pertama dan didapatkan hasil swab angka bakteri $29 \mathrm{CFU} / \mathrm{cm}^{2}$. Angka bakteri yang didapat berdasarkan hasil swab lantai pada kamar operasi 2 dan kamar operasi 3 sebelum ronde 1 dimulai tidak sesuai dengan nilai angka standart, pendapat Sabarguna \& Rubaya (2011) yaitu untuk lantai ruang operasi harus bersih dan memiliki tingkat kebersihan $0-5 \mathrm{CFU} / \mathrm{cm}^{2}$ dan bebas dari patogen dan gas gangren. Adanya mikroorganisme E.coli pada kamar operasi 2 dan 3 sebelum dilakukan pembersihan bernilai negatif. Hal tersebut dikarenakan adanya jeda waktu kurang lebih 3 jam dari waktu pertama kali pembersihan lantai yang dilakukan oleh petugas pembersihan. Dengan adanya jeda waktu tersebut, banyak petugas kamar operasi yang melakukan buka tutup pada kamar operasi 2 dan kamar operasi 3 untuk meyiapkan perlengkapan dan peralatan operasi yang akan dilaksanakan. Selain itu, saat dilakukan pengambilan swab yang telah ditentukan oleh peneliti (titik pengambilan sampel berjarak $\pm 20 \mathrm{~cm}$ dari meja operasi) terdapat adanya bekas tumpahan providone iodine yang telah mengering dan tidak terkena usapan pembersihan lantai kamar operasi 2 oleh petugas pembersihan yang dilakukan pada pagi hari dikarenakan kamar operasi 2 sering digunakan untuk operasi cito. Untuk titik pengambilan swab pada lantai kamar operasi 3, lantai dalam keadaan bersih dan kering tidak ada bekas tumpahan cairan apapun. Kemudian untuk sandal yang digunakan petugas kamar operasi dan petugas pembersihan kamar operasi tidak dilakukan penggantian dan tetap menggunakan sandal yang sama dengan sandal yang digunakan diluar ruangan kamar operasi. Dimana sandal tersebut dilakukan pembersihan hanya seminggu satu kali setiap pembersihan mingguan dikamar operasi tersebut.

Jenis operasi yang dilakukan di kamar operasi 2 pada ronde 1 ialah operasi SC (Sectio Caesarea) sedangkan untuk kamar operasi 3 ialah operasi Hemoroid. Tim operasi yang melakukan operasi pada kamar operasi 2 dan kamar operasi 3 tersebut berjumlah 5 orang tim tetap yang terdiri dari operator, asisten operator, instrumen, sirkuler, dan penata anestesi. Untuk kamar operasi 2 bertambah 1 orang perawat bayi yang menunggu didalam kamar operasi dari awal pembedahan dimulai hingga proses bayi selesai dikeluarkan kemudian perawat bayi tersebut keluar dari kamar operasi. Selama proses operasi berlangsung, tidak banyak petugas lain yang keluar masuk kamar operasi ini. Setelah operasi selesai, peralatan dan perlengkapan didalam kamar operasi ini dibereskan dan kemudian dilakukan pembersihan lantai oleh petugas pembersihan kamar operasi.

Selama pembersihan lantai berlangsung peneliti melakukan observasi terhadap petugas pembersihan dan didapatkan total skor cukup untuk pembersihan lantai yang dilakukan dikamar operasi 2 dan kamar operasi 3 pada ronde 1. Setelah dilakukan pembersihan, peneliti menunggu \pm 15 menit untuk mengambil sampel swab yang kedua yaitu pukul 10.15 WIB untuk kamar operasi 2 dan didapatkan hasil swab angka bakteri sebesar $2 \mathrm{CFU} / \mathrm{cm}^{2}$. Sedangkan untuk kamar operasi 3 dilakukan pengambilan sampel pada pukul 10.25 WIB dan didapatkan 
hasil swab $5 \mathrm{CFU} / \mathrm{cm}^{2}$. Nilai standart angka bakteri untuk lantai kamar operasi 2 dan kamar operasi 3 setelah dilakukan pembersihan sesuai dengan pendapat Sabarguna \& Rubaya (2011) yaitu untuk lantai ruang operasi harus bersih dan memiliki tingkat kebersihan $0-5 \mathrm{CFU} / \mathrm{cm}^{2}$ dan bebas dari patogen dan gas gangren. Pada kamar operasi 2 dan kamar operasi 3, kandungan mikroorganisme E.coli setelah dilakukan pembersihan pada ronde 1 semuanya bernilai negatif (-). Angka bakteri lantai sebelum dan setelah dilakukan pembersihan pada ronde 1 dikamar operasi 2 dan 3 mengalami penurunan. Hal ini sesuai dengan penelitian Nisa' (2016) yang mengatakan bahwa ada perbedaan angka bakteri sebelum dan setelah dilakukan pembersihan dilantai kamar operasi.

Hasil observasi yang dilakukan terhadap petugas pembersihan yang melakukan pembersihan lantai kamar operasi didapatkan total skor cukup dari jumlah total skor 6 untuk pembersihan lantai kamar operasi 2 dan kamar operasi 3. Dimana prosedur pembersihan lantai kamar operasi yang dilakukan oleh petugas pembersihan ialah larutan desinfektan klrorin $0,05 \%$ yang digunakan telah diencerkan sesuai dengan prosedur, kain pembersih lantai yang digunakan untuk pembersihan lantai pada ronde 1 ini merupakan kain yang baru bukan kain bekas dari pembersihan sebelumnya, dan kain pembersih lantai dalam keadaan kering. Berdasarkan dari hasil observasi yang dilakukan peneliti, dari jumlah hasil observasi yang telah dilakukan terhadap petugas pembersihan lantai kamar operasi telah melakukan pembersihan sesuai dengan prosedur pembersihan lantai kamar operasi yang ada. Dalam pelaksanaan pembersihan lantai kamar operasi zona 4, AHU-HEPA yang ada di kamar operasi 2 dan 3 telah menyala.

Hasil swab yang didapatkan pada lantai kamar operasi 2 sebelum dilakukan pembersihan pada lantai kamar operasi oleh petugas pembersihan kamar operasi sebelum ronde 3 dimulai yaitu menunjukkan jumlah koloni bakteri $12 \mathrm{CFU} / \mathrm{cm}^{2}$. Sedangkan untuk kamar operasi 3 menunjukkan jumlah koloni bakteri $15 \mathrm{CFU} /$ $\mathrm{cm}^{2}$ dimana pengambilan swab dilakukan pada pukul 11.55 WIB. Pada kamar operasi 2 dan kamar operasi 3, kandungan mikroorganisme E.coli sebelum dilakukan pembersihan lantai semuanya bernilai negatif (-). Dari kedua hasil swab tersebut menunjukkan bahwa pada saat sebelum ronde 3 dimulai, nilai standart angka bakteri untuk lantai tidak sesuai dengan pendapat Sabarguna \& Rubaya (2011) yaitu untuk lantai ruang operasi harus bersih dan memiliki tingkat kebersihan 0-5 CFU/ $\mathrm{cm}^{2}$ dan bebas dari patogen dan gas gangren.

Analisa efektifitas pembersihan lantai kamar operasi zona 4 terhadap jumlah koloni bakteri didapatkan hasil uji statistik dengan menggunakan uji korelasi spearman ialah sig (2-tailed) sebesar 0,004 . Hal ini menunjukkan bahwa $\mathrm{p}$ value $<\alpha$ $(0,05)$ atau $0,004<0,05$, maka hipotesis dalam penelitian ini diterima atau $\mathrm{H} 1$ diterima yang berarti menunjukkan bahwa ada keefektifitasan pembersihan lantai kamar operasi zona 4 terhadap jumlah koloni bakteri di Intalasi Bedah Sentral (IBS) RSUD Ngudi Waluyo Wlingi.

\section{PENUTUP}

Pembersihan lantai kamar operasi yang dilakukan oleh petugas pembersihan kamar operasi menurut hasil observasi yang dilakukan paling tinggi mendapatkan total skor cukup atau $50 \%$ pembersihan telah dilakukan sesuai prosedur pembersihan yang ada dikamar operasi RSUD Ngudi Waluyo Wlingi.

Jumlah koloni bakteri pada kamar operasi 2 sebelum dilakukan pembersihan setiap rondenya mengalami peningkatan dan setelah dilakukan pembersihan lantai kamar operasi 2 oleh petugas pembersihan mengalami peningkatan dari setiap rondenya. Sedangkan pada kamar operasi 3 terjadi penurunan jumlah koloni bakteri pada ronde 3 sebelum dilakukan 
pembersihan dan setelah dilakukan pembersihan terjadi penurunan angka bakteri pada ronde ke 2.

Nilai angka bakteri pada kamar operasi 2 dan operasi 3 sebelum dilakukan pembersihan tidak sesuai dengan standar nilai angka bakteri dan setelah dilakukan pembersihan oleh petugas pembersihan ada yang sesuai dengan standar angka bakteri menurut Kemenkes dan ada yang tidak sesuai dengan standar nilai angka bakteri menurut Kemenkes. Sedangkan pembersihan yang dilakukan tidak $100 \%$ sesuai dengan prosedur yang ada dikamar operasi RSUD Ngudi Waluyo Wlingi.

Dengan hasil penelitian ini diharapkan dapat menambah wawasan dan pengetahuan serta keterampilan petugas pembersihan dalam pelaksanaan pembersihan lantai kamar operasi. Sebagai masukan untuk petugas pembersihan, sebaiknya saat sebelum dimulai operasi pada ronde 1 dilakukan pembersihan lantai kembali untuk meminimalkan pertumbuhan bakteri dilantai kamar operasi. Petugas pembersihan dalam meningkatkan kualitas pembersihan dikamar operasi dapat mengikuti pelatihan petugas pembersihan kamar operasi terutama tentang pencegahan infeksi nosokomial.

\section{DAFTAR PUSTAKA}

Darmadi. (2008). Infeksi Nosokomial: problematika dan pengendaliannya. Jakarta: Salemba Medika.

Depkes, RI. (1993). Pedoman Kerja Perawat Kamar Operasi. Jakarta.
Depkes, RI. (1997). Pedoman Pelayanan Pusat Sterilisasi di Rumah Sakit Pendidikan. Jakarta.

Kasmad, S. U \& Hidayati, W. (2007). Hubungan antara Kualitas Perawatan Kateter dengan Kejadian Infeksi Nosokomial Saluran Kemih, Jurnal Keperawatan UNDIP volume 1, no. 1 tahun 2007. Semarang: FK UNDIP.

Kemenkes, RI. (2004). Keputusan Menteri Kesehatan Republik Indonesia Nomor 1204/MENKES/SK/X/2004 tentang Pesyaratan Kesehatan Lingkungan RS. Jakarta.

Kemenkes, RI. (2012). Pedoman Teknis Ruang Operasi Rumah Sakit. Jakarta.

Nisa', D. Z. (2016). Efektivitas Penggunaan Cairan Desinfektan Ammonium Kuartener terhadap Jumlah Kuman pada Pembersihan Harian di Kamar Operasi $R S$ Lavalette Malang. Poltekkes Kemenkes Malang.

Sabarguna, B. S \& Rubaya, A. K. (2011). Sanitasi Lingkungan dan Bnagunan Pendukung Kepuasan Pasien Rumah Sakit. Jakarta: Salemba Medika.

Taek, F. (2010). Surveilans epidemiologi.Jurnal Kesehatan Volume 1 Tahun 2010. Poltekkes Kemenkes Kupang.

Tamher, S. (2008). Mikrobiologi untuk Mahasiswa Keperawatan. Jakarta: CV Trans Info Media.

Wulandari, w., dkk. (2015). Angka Kuman Udara dan Lantai Ruang Rawat Inap Rumah Sakit PKU Muhammadiyah Yogyakarta. Yogyakarta 